\title{
ॠUSGS
}

science for a changing world

\section{Digital Elevation Models of the Pre-Eruption 2000 Crater and 2004-07 Dome-Building Eruption at Mount St. Helens, Washington, USA}

By J.A. Messerich, S.P. Schilling, and R.A. Thompson

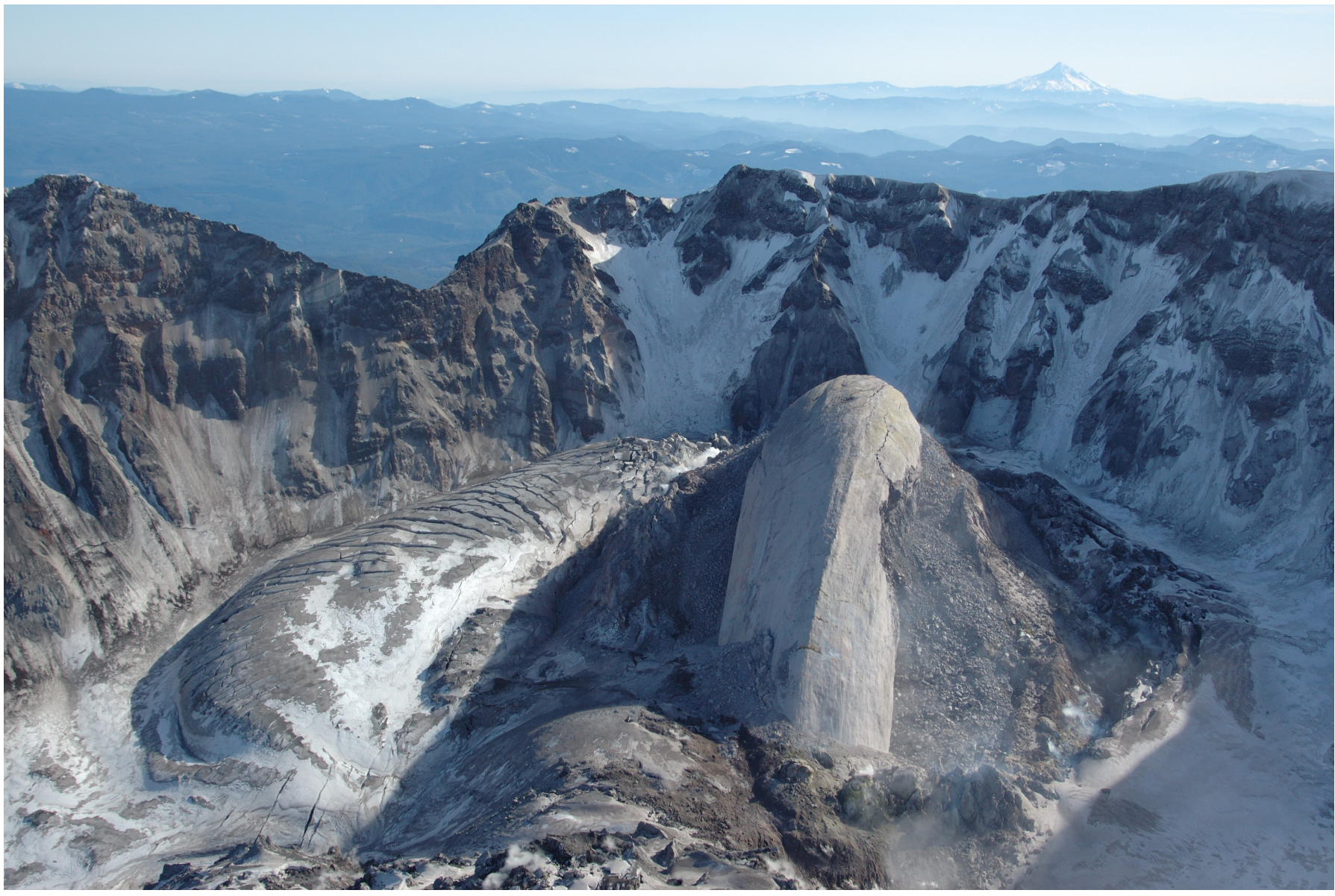

Open-File Report 2008-1169

U.S. Department of the Interior

U.S. Geological Survey 


\section{U.S. Department of the Interior DIRK KEMPTHORNE, Secretary}

\section{U.S. Geological Survey \\ Mark D. Myers, Director}

U.S. Geological Survey, Reston, Virginia: 2008

For product and ordering information:

World Wide Web: http://www.usgs.gov/pubprod

Telephone: 1-888-ASK-USGS

For more information on the USGS - the Federal source for science about the Earth, its natural and living resources, natural hazards, and the environment:

World Wide Web: http://www.usgs.gov

Telephone: 1-888-ASK-USGS

Suggested citation:

Messerich, J.A., Schilling, S.P., and Thompson, R.A., 2008, Digital Elevation Models of the Pre-Eruption 2000 Crater and 2004-07 Dome-Building Eruption at Mount St. Helens, Washington, USA: U.S. Geological Survey Open-File Report 2008-1169, 2 p.

Any use of trade, product, or firm names is for descriptive purposes only and does not imply endorsement by the U.S. Government.

Although this report is in the public domain, permission must be secured from the individual copyright owners to reproduce any copyrighted material contained within this report.

Cover: Photograph of Mount St. Helens dome on February 22, 2005. Photograph by S.P. Schilling. 


\section{Digital Elevation Models of the Pre-Eruption 2000 Crater and 2004-07 Dome-Building Eruption at Mount St. Helens, Washington, USA}

\section{Abstract}

Presented in this report are 27 digital elevation model (DEM) datasets for the crater area of Mount St. Helens. These datasets include pre-eruption baseline data collected in 2000, incremental model subsets collected during the 2004-07 dome-building eruption, and associated shaded-relief image datasets. Each dataset was collected photogrammetrically with digital softcopy methods employing a combination of manual collection and iterative compilation of $\mathrm{x}, \mathrm{y}, \mathrm{z}$ coordinate triplets utilizing autocorrelation techniques. DEM data points collected using autocorrelation methods were rigorously edited in stereo and manually corrected to ensure conformity with the ground surface. Data were first collected as a triangulated irregular network (TIN) then interpolated to a grid format. DEM data are based on aerotriangulated photogrammetric solutions for aerial photograph strips flown at a nominal scale of 1:12,000 using a combination of surveyed ground control and photograph-identified control points. The 2000 DEM is based on aerotriangulation of four strips totaling 31 photographs. Subsequent DEMs collected during the course of the eruption are based on aerotriangulation of single aerial photograph strips consisting of between three and seven 1:12,000-scale photographs (two to six stereo pairs). Most datasets were based on three or four stereo pairs. Photogrammetric errors associated with each dataset are presented along with ground control used in the photogrammetric aerotriangulation. The temporal increase in area of deformation in the crater as a result of dome growth, deformation, and translation of glacial ice resulted in continual adoption of new ground control points and abandonment of others during the course of the eruption. Additionally, seasonal snow cover precluded the consistent use of some ground control points. 


\section{Purpose}

The 2000 DEM dataset was collected to assess the state of geomorphic change associated with the post-1980-86 crater of Mount St. Helens and to provide suitable base materials for ongoing geologic mapping efforts supported by the USGS Volcano Hazards Program and National Cooperative Geologic Mapping Program. The 2004-07 DEM datasets were collected as part of the U.S. Geological Survey volcano-monitoring effort at Mount St. Helens. The primary application of the data is for quantitative monitoring of geomorphic and volumetric change associated with dome growth and glacial deformation and derivation of magma extrusion rates.

\section{Data}

The digital elevation model (DEM) datasets are downloadable using the links below. The DEM data files are available as ArcInfo .e00 files. ArcInfo-compatible GIS software is required to import the data. Also available for download are small digital shaded-relief images of each DEM dataset in jpeg format and compiled as a short movie (MSH_wdates.wmv). The user is referred to the metadata file (MSH_OFR-1169.met), supplemental data documentation (supplemental_DEM_info.doc), and individual aerotriangulation reports for additional information regarding photogrammetric aerotriangulation results and associated errors for each dataset. All downloadable data are stored as compressed .zip files for ease of data transfer and will need to be uncompressed with appropriate software before use.

Download MSH DEMs.zip containing the ArcInfo .e00 files

Download MSH IMAGES.zip containing the shaded-relief jpeg image files

Download MSH INFO.zip containing the metadata and supplemental information files

Download MSH MOVIE.zip containing the DEM movie file 